\title{
Bacterial colonization of transparent exopolymeric particles in mesocosms under different turbulence intensities and nutrient conditions
}

\author{
M. L. Pedrotti ${ }^{1, *}$, S. Beauvais ${ }^{1}$, M.-E. Kerros ${ }^{1}$, K. Iversen $^{2}$, F. Peters ${ }^{3}$ \\ ${ }^{1}$ Marine Microbial Ecology Group, Laboratoire d'Océanographie de Villefranche, University of Paris VI, CNRS UMR 7093, \\ Observatoire Océanologique de Villefranche-sur-Mer, Station Zoologique, BP 28, 06234 Villefranche-sur-Mer, France \\ ${ }^{2}$ Department of Aquatic Biosciences, Norwegian College of Fishery Science, University of Tromsø, Breivika, \\ 9037 Tromsø, Norway \\ ${ }^{3}$ Institut de Ciències del Mar, CMIMA (CSIC) Passeig Maritim de la Barceloneta, 08003 Barcelona, Catalunya, Spain
}

\begin{abstract}
We examined bacterial colonization of transparent exopolymeric particles (TEP) in nutrient-manipulated mesocosms subjected to different turbulence intensities. We quantified heterotrophic bacterial abundance, production and diversity using fluorescence in situ hybridization (FISH). The abundance of attached bacteria increased significantly with TEP size in all treatments. The slope values of the number of bacteria scaled with TEP size varied from 1.15 on Day 1 to 2.04 on Day 11 in still and turbulent tanks, respectively. Comparison between these slopes indicated that the number of attached bacteria for a given TEP diameter was higher under turbulence. The addition of nutrients and turbulence in mesocosms neither supported higher bacterial abundance nor resulted in a correlation between bacterial concentrations and TEP. However, in enriched turbulent tanks, the number of attached bacteria was higher and was linked to rapid TEP formation after the diatom bloom. This was accompanied by higher bacterial production $\left(1.21 \mu \mathrm{mol} \mathrm{C}^{-1} \mathrm{~d}^{-1}\right.$ at the intermediate level of turbulence on Day 9), which was positively related to TEP. These correlations highlight the finding that higher bacterial productivity was due to a larger fraction of attached bacteria (up to $56.4 \%$ ). Changes in bacterial production occurred with simultaneous changes in the community structure, i.e. the percentages of the Cytophaga-Flavobacteria-Bacteroides cluster increased significantly. By Day 9, this cluster became the dominant group of bacteria attached to TEP (85 and 90\%, respectively at intermediate and high levels of turbulence). Among the marine heterotrophic bacterioplankton, this phylum is known to be common as attached bacteria. Therefore, it seems that the added nutrients and subsequent TEP production can be used by bacteria more efficiently under turbulent conditions through a shift in group-specific composition towards more attached bacteria with higher production rates.
\end{abstract}

KEY WORDS: Transparent exopolymer particles · Particle colonization • Bacteria · FISH · Turbulence · Nutrients $\cdot$ Mesocosms

Resale or republication not permitted without written consent of the publisher

\section{INTRODUCTION}

A large portion of organic matter in the marine environment is processed in the microbial loop through heterotrophic bacteria. Bacterioplankton thus play a central role in biogeochemical cycling, not only in the cycling of carbon, but also in the cycling of elements that limit phytoplankton growth (Azam et al. 1983).
Pelagic microorganisms inhabit a strongly structured aquatic environment characterized by a continuum of organic matter composed of colloids (Wells \& Goldberg 1994), submicrometer particles (Koike et al. 1990) and other detrital particles of various chemical compositions and sizes, which are present in high concentrations in seawater (Alldredge et al. 1993, Verdugo et al. 2004). Among these particles are transparent exopoly- 
meric particles (TEP), which are enriched in carbon relative to nitrogen or phosphorus, and appear to be a key element in the fluxes of organic matter in coastal and oceanic ecosystems (Mari et al. 2001, Engel et al. 2004).

TEP constitute a suitable site for bacterial colonization (Passow \& Alldredge 1994). In marine pelagic environments, the number of bacteria colonizing TEP varies from 5 to $40 \%$, and in some cases $89 \%$ of the total bacterial numbers (Passow \& Alldredge 1994, Schuster \& Herndl 1995, Mari \& Kiørboe 1996). Bacteria themselves may act in the formation of TEP by secreting polysaccharides as free exopolymers or capsular material (Stoderegger \& Herndl 1998). Also, the high hydrolytic enzyme activity of bacteria in aggregates, including TEP, suggests their degradation and/or consumption by bacteria that mediate the transformation of particulate organic matter to a dissolved phase (Smith et al. 1992, Smith et al. 1995, Radic et al. 2006). These processes do not only account for the higher bacterial activity of aggregates but are also responsible for the observed difference in the composition between attached and free-living bacterial communities in marine and freshwater systems (DeLong et al. 1993, Knoll et al. 2001, Simon et al. 2002).

Several factors such as nutrient supply, phytoplankton, grazers and viruses are known to affect the structure and activities of bacterial communities (Riemann et al. 2000). Theoretical and experimental studies have shown that small-scale turbulence strongly influences the structure of pelagic food webs by changing the phytoplankton diffusion layer (Mann \& Lazier 1996), nutrient dynamics and fluxes to osmotrophic organisms (Karp-Boss et al. 1996). Although bacteria are below the theoretical size limit in which eddy motion can directly enhance production (Lazier \& Mann 1989), this view is changing, as organisms $1000 \times$ smaller than the Kolmogorov microscale may be affected by some residual inertial motion (Hill et al. 1992). It has been suggested that turbulent mixing influences motility and microspatial distribution of marine bacteria due to chemotactic behavior and physiological responses of bacteria (Bowen et al. 1993, Seymour et al. 2000). Turbulence may also directly or indirectly affect bacterial dynamics, activity and mortality (Dolan et al. 2003, Malits et al. 2004). Malits et al. (2004) showed that small-scale turbulence could directly affect bacterial communities by increasing bacterial size and altering bacterial morphology. Turbulence may also indirectly affect bacterial abundance, growth and respiration through food web interactions (Peters et al. 2002, Bergstedt et al. 2004).

According to Pinhassi et al. (2004), changes in bacterioplankton species composition are dependent on a dominant phytoplankton group and also on turbu- lence. Furthermore, turbulence affects the dynamics of suspended particles by increasing collision and coagulation rates (Kiørboe 1997). The newly released colloidal organic matter coagulates much faster under turbulence than under still conditions (Stoderegger \& Herndl 1999). Turbulence promotes TEP aggregation, and depending on its intensity, modulates carbon export by maintaining the TEP pool at the surface or enhancing sedimentation (Beauvais et al. 2006). It is thus of primary importance in furthering our understanding of pelagic systems to determine how bacteria interact with organic matter and conversely, in what way the structure and complexity of the organic matter influence bacterial distribution.

Here we report on the bacterial colonization of TEP in mesocosms under different turbulence intensities and nutrient conditions. TEP dynamics and phytoplankton responses from this experiment have been reported elsewhere (Beauvais et al. 2006). The characterization of the bacterial communities employed fluorescent in situ hybridization (FISH) techniques, which have been successfully applied to detrital particles (Lemarchand et al. 2006). In this study, we set out to investigate (1) bacterial colonization of transparent exopolymeric particles (TEP), (2) the role of TEP as an organic substrate for bacteria, (3) the influence of turbulence on changing substrate availability for bacteria and (4) whether these changes are accompanied by comparable changes in the composition and activity of particle-associated bacteria.

\section{MATERIALS AND METHODS}

Study site and sampling. The mesocosm experiment was carried out at the Marine Biological Field Station (Espeland, Norway) from July 10 to 25, 2001 in the framework of the European NTAP program (Nutrient dynamics mediated through turbulence and plankton interactions). The mesocosms consisted of 12 on-land cylindrical polyethylene tanks $\left(2.6 \mathrm{~m}^{3}, 1.5 \mathrm{~m}\right.$ diameter, $1.5 \mathrm{~m}$ depth) filled with postbloom seawater from $5 \mathrm{~m}$ depth of the Raunefjorden fjord. The subsurface water was screened through a $250 \mu \mathrm{m}$ mesh nylon netting to remove most metazoan grazers (see Beauvais et al. 2006 for details). For the analyses of attached bacteria, 6 mesocosms were sampled.

The tanks were divided into 2 treatment series: one series received no nutrients ( $\mathrm{T}$ tanks) while the other series was fertilized on Day 1 (NT tanks). The nutrient addition (16 $\mu \mathrm{M}$ N:1 $\mu \mathrm{M}$ P:32 $\mu \mathrm{M}$ Si) followed the Redfield ratio. In both treatments, tanks were exposed to different turbulence intensities: $5 \times 10^{-2}$ to $8 \times 10^{-2}$ (T2 and NT2) and $1 \mathrm{~cm}^{2} \mathrm{~s}^{-3}$ (T4 and NT4). Two sets of mesocosms were not subjected to artificial turbulence 
(still mesocosms: T0 and NT0) where the energy dissipation rate measured was $2 \times 10^{-5} \mathrm{~cm}^{2} \mathrm{~s}^{-3}$. The measured dissipation rates are in the range of realistic levels of turbulence found in the euphotic zone, notably in coastal areas (MacKenzie \& Legget 1993). Turbulence was generated using vertically oscillating grids placed at a depth of $1 \mathrm{~m}$ and with a vertical stroke of $40 \mathrm{~cm}$ in order to create nearly homogeneous conditions. Each grid consisted of a steel frame that was covered with Teflon and 2 Plexiglas grids $(10 \mathrm{~cm}$ opening, $5 \mathrm{~cm}$ grid width) attached to it. An acoustic Doppler flow meter was used to measure water velocity and turbulent kinetic energy. Dissipation rates in $\mathrm{cm}^{2} \mathrm{~s}^{-3}$ were calculated from energy spectra using a linear regression method (Stiansen \& Sundby 2001).

Integrated samples were taken every other day from each mesocosm using Plexiglas tubes $(5 \mathrm{~cm}$ diameter, $1.5 \mathrm{~m}$ depth), at 09:00 h. Subsamples were collected for the determination of suspended chl $a$, TEP and for bacterial analysis. The chl a concentration was analyzed fluorimetrically on $90 \%$ acetone extracts (Parsons et al. 1984).

TEP determination and bacterial colonization of TEP. Water samples for TEP determination and bacterial colonization were collected every second day. Samples (5 to $10 \mathrm{ml}$ ) were fixed with $2 \%$ formaldehyde and gently filtered through $0.2 \mu \mathrm{m}$ white Nuclepore filters. TEP and bacteria retained on the filter were stained with $500 \mu \mathrm{l}$ of an aqueous solution of $0.06 \%$ acetic acid $(\mathrm{pH} 2.5)$ and $0.02 \%$ Alcian blue 8GX. Filters were mounted on a white Cyto-Clear slide (Logan et al. 1994) after double staining with DAPI. This technique allows direct observations of TEP and bacteria on the filter. Slides were stored at $-20^{\circ} \mathrm{C}$ in the dark until analysis using an Axiophot-Zeiss epifluorescence microscope. Pictures were captured with a CCD color video camera $(752 \times 582$ pixels resolution, 0.08 lux minimum sensitivity). Two pictures of a unique field were taken simultaneously at $630 \times$ magnification, one under UV light to count total bacteria, and the other under transmission light to observe TEP. For each filter, an average of 500 bacteria and 70 ind. TEP were counted and sized.

The TEP perimeter was traced semi-automatically and the equivalent spherical diameter (ESD) of an individual TEP was then calculated from area measurements assuming the symmetry of a sphere. Counts were binned by ESD into 12 logarithmic size classes between 1 and $56 \mu \mathrm{m}$. Attached bacteria were counted by overlaying the 2 pictures (at $630 \times$ magnificaion) for direct and simultaneous visualization of free and TEPattached bacteria. We also estimated the fraction of free-living bacteria retained beneath or on TEP during filtration. The number of retained bacteria represented $2.8 \pm 1.3 \%$ of the total bacterial count $(1$ to $6 \% ; n=51)$. Considering the low values, this fraction was not included in the calculations. Two replicate filters were counted. For each sample, the relationship between the number of attached bacteria per TEP (n) and the size of the TEP was calculated. The number of attached bacteria was fitted to a power law function, $n=\mathrm{a} d^{\mathrm{b}}$, where $d$ is the equivalent spherical TEP diameter, and $\mathrm{a}$ and $\mathrm{b}$ are constants for a given sample. The constants were obtained from log-log plots of $n$ vs. $d$. TEP concentration was given in $\# \mathrm{ml}^{-1}$ and carbon content (TEP-C, $\mu \mathrm{g} \mathrm{C} \mathrm{ml}^{-1}$ ) was determined from the size-frequency distribution using the size-dependent relationship proposed by Mari (1999):

$$
\text { TEP-C }=0.25 \Sigma_{i} n_{i} r_{i}^{2.55}
$$

where $n_{i}$ is the concentration of particles in size class $i_{\text {, }}$ and $r_{i}$ is the TEP radius $(\mu \mathrm{m})$ for the same size class.

Calculation of the fraction of TEP-attached bacteria. The magnification $(630 \times)$ used to count TEP and bacteria simultaneously may underestimate both large TEP and small bacteria. Thus, the fraction of total TEPattached bacteria to the total bacterial count in different treatments was calculated according to Passow \& Alldredge (1994) by combining (1) the general relationship between the number of attached bacteria per TEP $(n)$ and the size of the TEP $\left(n=\mathrm{a} d^{\mathrm{b}}\right)$ as described in previous section, (2) total bacterial counts (obtained using $0.2 \mu \mathrm{m}$ DAPI filters at $1000 \times$ magnification) as described in the following section, and (3) the size distribution of TEP determined by Beauvais et al. (2006) for the same experiment. Beauvais et al. (2006) counted a minimum of 600 TEP for each sample at 3 successive magnifications $(100 \times, 200 \times, 400 \times)$ to cover the entire size spectra.

We also estimated the 'encounter rate kernel' of bacteria with TEP based on the model of Kiørboe et al. (2002) for bacterial colonization of aggregates. The volume of water from which the TEP collected bacteria per unit time $(B$, also called encounter probability rate, in terms of $\mathrm{cm}^{3} \mathrm{TEP}^{-1} \mathrm{~s}^{-1}$ ) was calculated as:

$$
B=4 \times \pi \times D \times r_{\mathrm{TEP}} \times \mathrm{Sh}
$$

where $D$ is the diffusion coefficient of bacteria, $r$ is the TEP radius and Sh is the Sherwood number. We used a diffusion coefficient of $0.4 \times 10^{-6} \mathrm{~cm}^{2} \mathrm{~s}^{-1}$, as estimated by Kiørboe et al. (2002) for a marine bacterium. The Sh value in the absence of advection is 1 . According to Kiørboe et al. (2002), colonizing bacteria detach from aggregates after relatively short residence times, so we assumed $1 \mathrm{~h}$ as the residence time of bacteria colonizing TEP prior to detachment. $B$ was calculated for each of the 12 size classes of TEP, and TEP concentration was normalized (TEP $\mathrm{ml}^{-1}$ ) for each specific size class. Results are the predicted number of bacteria attached for each TEP size class per $\mathrm{ml}$ for each treatment and sampling day. 
Bacterial abundance and heterotrophic production. Water samples for bacterial abundance and production were collected every second day. Total bacterial abundance was determined by direct counting. Water samples $(5 \mathrm{ml})$ were preserved with $2 \%(\mathrm{wt} / \mathrm{vol})$ formaldehyde, stained with DAPI (final concentration, $0.25 \mu \mathrm{g}$ $\mathrm{ml}^{-1}$ ) for $5 \mathrm{~min}$, and filtered onto black $0.2 \mu \mathrm{m}$ polycarbonate filters (Porter \& Feig 1980). Between 500 and 600 bacteria were counted with an Axiophot-Zeiss epifluorescence microscope at $1000 \times$ magnification. Heterotrophic bacterial production was measured by the incorporation of tritiated leucine in bacterial protein synthesis according to Kirchman et al. (1985). The samples were incubated in the dark at in situ temperatures with $60 \mathrm{nM}\left[{ }^{3} \mathrm{H}\right]$ leucine (Amersham, SA) for $1 \mathrm{~h}$, after which production was stopped by the addition of $100 \%$ trichloroacetic acid (TCA). Samples were stored in a refrigerator prior to counting in a Packard Tri Carb liquid scintillation analyzer (model $1900 \mathrm{~A}$ ). Results were

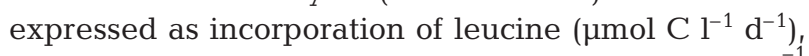
with the theoretical conversion factor of $3.1 \mathrm{~kg} \mathrm{C} \mathrm{mol}^{-1}$ being used to convert leucine incorporation rates to bacterial carbon production (Simon \& Azam 1989).

Fluorescent in situ hybridization. The composition of the total bacterial community was determined on Days $0,1,2,3,5$, and 9 by using FISH. Bacterial cells from 10 to $40 \mathrm{ml}$ subsamples were fixed with $2 \%$ formalin, filtered onto $0.2 \mu \mathrm{m}$ white polycarbonate membrane filters ( $47 \mathrm{~mm}$ diameter), and stored at $-20^{\circ} \mathrm{C}$. On Day 9, the community of TEP-attached bacteria was also studied. Bacterial cells were filtered onto $0.2 \mu \mathrm{m}$ polycarbonate filters ( $25 \mathrm{~mm}$ diameter), stained with Alcian blue, and hybridized using different probes. Experiments showed that it is possible to combine TEP techniques and FISH probes; counts of positive cells before and after staining filters with Alcian blue did not differ.

The probes used were ARCH915 for Archaea and EUB338 for Eubacteria (Amann et al. 1990). The group-specific probes for the detection of the Alpha, Beta and Gamma subclasses of Proteobacteria were ALF968, BET42a and GAM42a, and CF319 to detect members of the Cytophaga-Flavobacterium cluster of phylum CFB. A negative probe (Non 338) was used as negative control. Probes BET42a and GAM42a were used with a competitor oligonucleotide. Probes were labeled with the indocarbocyanine fluorescent dye CY3 (Interactiva). Hybridization, washing and DAPI staining procedures were adapted from Ouverney \& Fuhrman (2000) and Pernthaler et al. (2001). The hybridization buffer contained $0.9 \mathrm{M} \mathrm{NaCl}, 20 \mathrm{mM}$ Tris- $\mathrm{Cl}, 10 \%$ dextran sulphate, $0.01 \%$ polyadenylic acid, $0.2 \%$ bovine serum albumin, and $0.01 \%$ sodium dodecyl sulphate (SDS), and was used with a variable concentration of formamide. Hybridization was per- formed at $46^{\circ} \mathrm{C}$ for 3 to $4 \mathrm{~h}$, with a probe concentration of $5 \mathrm{ng} \mathrm{ll}^{-1}$. Filters were then incubated in a washing buffer composed of $20 \mathrm{mM}$ Tris- $\mathrm{HCl}$, a variable concentration of $\mathrm{NaCl}, 5 \mathrm{mM}$ EDTA and a SDS solution, at $48^{\circ} \mathrm{C}$ for 10 to $15 \mathrm{~min}$ in the dark. Filters were then stained with DAPI and mounted in a 4:1 mixture of Citifluor and Vecta Shield on glass slides. Counting was performed using a Zeiss epifluorescence microscope equipped with appropriate filter sets. On the same filter, at least 500 DAPI-stained cells were counted under UV light and CY3-positive cells were counted under green light. For filters stained with Alcian blue on Day 9, attached bacteria stained with the specific probes were counted by switching between green light to visualize probe-labeled bacteria and visible light to count TEP.

Statistical analysis. Two-way ANOVA was used to test for significant differences in (1) the colonization rate of TEP between treatments, (2) the abundance of total bacteria between treatments, and (3) the relative abundance of Eubacteria between treatments. Total numbers of cells and the percentage of TEPattached cells in treatments were analyzed using nutrient and turbulence as fixed factors. A 2-way factorial covariance analysis (ANCOVA) for independent samples was used to test the effect of nutrients and turbulence on the slopes of regression lines between the number of attached bacteria (dependent variable) and the size of the TEP (concomitant variable). This was done for each sampling day (except Day 9). Statistical significance was accepted for $\mathrm{p}<$ 0.05. To determine the significance of the coefficient of determination $\left(\mathrm{r}^{2}\right)$, a $t$-test according to Fisher was performed. Potential relationships of TEP with bacterial abundance (total and attached) and bacterial production were tested using Pearson's correlation coefficient or linear regression.

\section{RESULTS}

\section{TEP abundance and bacterial colonization}

In non-enriched tanks, TEP occurred at low concentrations $\left(<3.5 \times 10^{4} \mathrm{ml}^{-1}\right)$ with no apparent temporal patterns (Fig. 1A). In nutrient-enriched tanks, TEP concentrations remained low until Day 3, then increased exponentially to reach $34 \times 10^{4} \mathrm{TEP} \mathrm{ml}^{-1}$ on Day 11 at the highest level of turbulence (NT4, Fig. 1A). In these tanks, the highest TEP concentration occurred subsequent to the diatom bloom as shown by the increase in the ratio of $\mathrm{chl} a(>10 \mu \mathrm{m})$ to total chl $a$ (Fig. 1 B) (see Beauvais et al. 2006 for more details on TEP dynamics and phytoplankton responses in this experiment). 

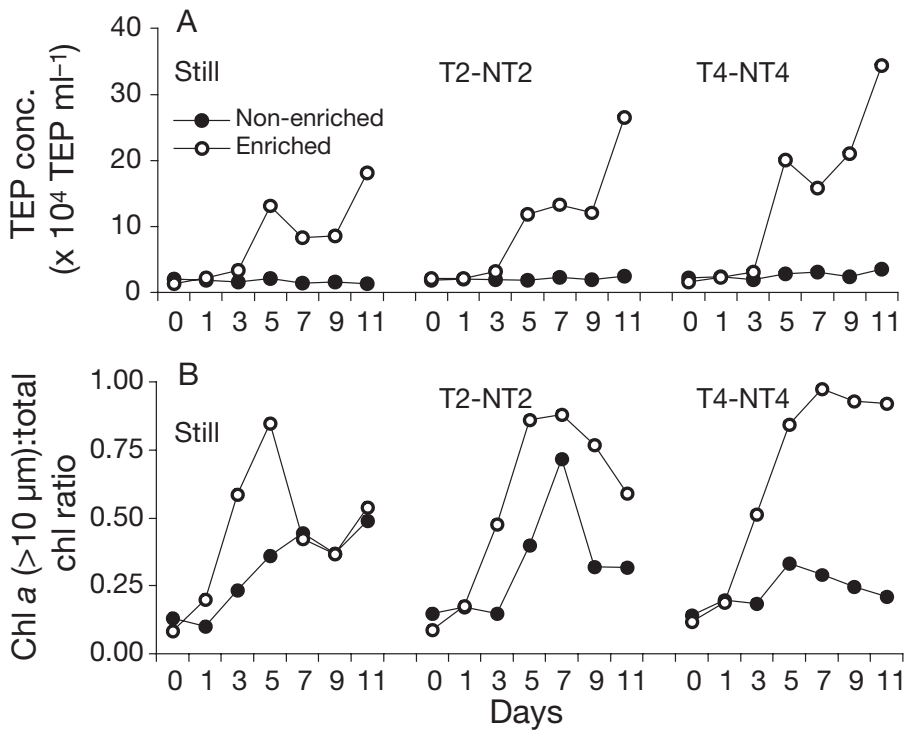

Fig. 1. (A) Transparent exopolymer particles (TEP) concentration (\# TEP $\times 10^{4} \mathrm{ml}^{-1}$ ) in different mesocosms. (B) Ratio of chl $a(>10 \mu \mathrm{m})$ to total chlorophyll in different mesocosms. For details of experimental conditions see 'Materials and methods', 'Study site and sampling'

Double-staining TEP with Alcian blue and DAPI indicated that bacteria commonly colonized particles. An average of $80 \pm 15 \%$ of TEP was colonized by bacteria with no significant differences between treatments (ANOVA; $F=2.42, \mathrm{p}=0.10, \mathrm{~N}=35$ ). The absolute number of bacteria attached to TEP (range: 1 to 60 bacteria $\mathrm{TEP}^{-1}$ ) increased significantly with TEP size, as described by a power law relationship, with bacterial numbers being scaled with TEP diameter raised to an exponent of 1.15 on Day 1 in still tanks
(NT0) and an exponent of up to 2.04 on Day 11 in turbulent tanks (T4) (average: $1.64 \pm 0.2$ ). All regressions in all treatments were highly significant $(\mathrm{p}<0.001)$ (Table 1, Fig. 2). The abundance of attached bacteria in the different treatments was compared by testing for differences in the regression lines relating the number of bacteria per TEP and the ESD of the particles for each treatment. At the beginning of the experiment and on Day 7, no significant differences were observed between treatments (ANCOVA, ns; Table 2). However, on Days 3, 5 and 11, the number of attached bacteria was significantly higher under turbulence (ANCOVA; $F=6.69,30$ and $5.22 ; \mathrm{p}=0.001,4.5 \times 10^{-13}$ and 0.005 for Days 3, 5 and 11, respectively), although the abundance of attached bacteria was not affected by the addition of nutrients (ANCOVA, ns). At the end of the experiment (Day 11), there was also a significant interaction between the 2 factors (nutrients and turbulence), suggesting that the effect of turbulence on attached bacteria was dependent on nutrient addition (ANCOVA; $F=3.86, \mathrm{p}=0.02$ ). In still tanks (T0 and NT0) and in non-enriched tanks (T2, T4), the numbers of attached bacteria did not differ significantly between the 2 levels of turbulence, whereas regression slopes in enriched turbulent tanks showed that higher numbers of attached bacteria were reached at the highest turbulence level (NT4; Table 1). Using the regressions we calculated the expected number of bacteria attached to 1 TEP (Fig. 2). We found that for a given diameter of TEP, bacterial colonization was higher under turbulence. For example, the average number of bacteria per TEP at an ESD of $10 \mu \mathrm{m}$ varies from 5 to 15 bacteria, the last value being found in mesocosms with turbulence on Day 11.

Table 1. Number of bacteria attached to a TEP $(n)$ as a function of its diameter $(d, \mu \mathrm{m})$ at different sampling dates (except Day 9$)$. Average values of the constants a and $\mathrm{b}$ come from the equation $n=\mathrm{a} d^{\mathrm{b}}$. All regression lines are highly significant $(\mathrm{p}<0.001)$. $\mathrm{N}$ is the number of TEP analysed. From Days 0 to 7, data from enriched and non-enriched tanks were pooled as no significant differences were observed in the effects of nutrients between tanks (see Table 2). For Day 11, data (N) from non-enriched and enriched tanks were separated due to the significant interaction between nutrient addition and turbulence (ANCOVA: $F=3.86$, $\mathrm{p}=0.02$ ). For details of experimental conditions see 'Materials and methods', 'Study site and sampling'

\begin{tabular}{|c|c|c|c|c|c|c|c|c|c|c|c|c|}
\hline & \multicolumn{4}{|c|}{ TO, NTO (Still: $2 \times 10^{-5} \mathrm{~cm}^{2} \mathrm{~s}^{-3}$ ) } & \multicolumn{4}{|c|}{$\begin{array}{l}\text { Turbulence treatments } \\
\text { T2-NT2 }\left(5-8 \times 10^{-1} \mathrm{~cm}^{2} \mathrm{~s}^{-3}\right)\end{array}$} & \multicolumn{4}{|c|}{ T4-NT4 $\left(1 \mathrm{~cm}^{2} \mathrm{~s}^{-3}\right)$} \\
\hline & $\mathrm{a}$ & $\mathrm{b}$ & $\mathrm{N}$ & $\mathrm{r}$ & $\mathrm{a}$ & $\mathrm{b}$ & $\mathrm{N}$ & $\mathrm{r}$ & a & $\mathrm{b}$ & $\mathrm{N}$ & $\mathrm{r}$ \\
\hline Day 0 & 0.37 & 1.58 & 138 & 0.66 & 0.38 & 1.58 & 165 & 0.70 & 0.37 & 1.75 & 124 & 0.71 \\
\hline Day 1 & 0.40 & 1.15 & 284 & 0.52 & 0.32 & 1.41 & 319 & 0.63 & 0.26 & 1.47 & 256 & 0.60 \\
\hline Day 3 & 0.28 & 1.62 & 342 & 0.70 & 0.22 & 1.71 & 354 & 0.62 & 0.32 & 1.75 & 312 & 0.79 \\
\hline Day 5 & 0.22 & 1.67 & 187 & 0.72 & 0.33 & 1.56 & 131 & 0.83 & 0.35 & 1.76 & 181 & 0.81 \\
\hline Day 7 & 0.22 & 1.47 & 156 & 0.74 & 0.34 & 1.65 & 69 & 0.90 & 0.26 & 1.92 & 170 & 0.82 \\
\hline Day 11 & 0.19 & 1.68 & 146 & 0.71 & & & & & & & & \\
\hline $\mathrm{T} 2-\mathrm{T} 4^{\mathrm{a}}$ & & & & & 0.18 & 1.97 & 63 & 0.83 & 0.14 & 2.04 & 98 & 0.89 \\
\hline NT2-NT4 ${ }^{b}$ & & & & & 0.22 & 1.76 & 117 & 0.73 & 0.33 & 1.90 & 104 & 0.81 \\
\hline
\end{tabular}




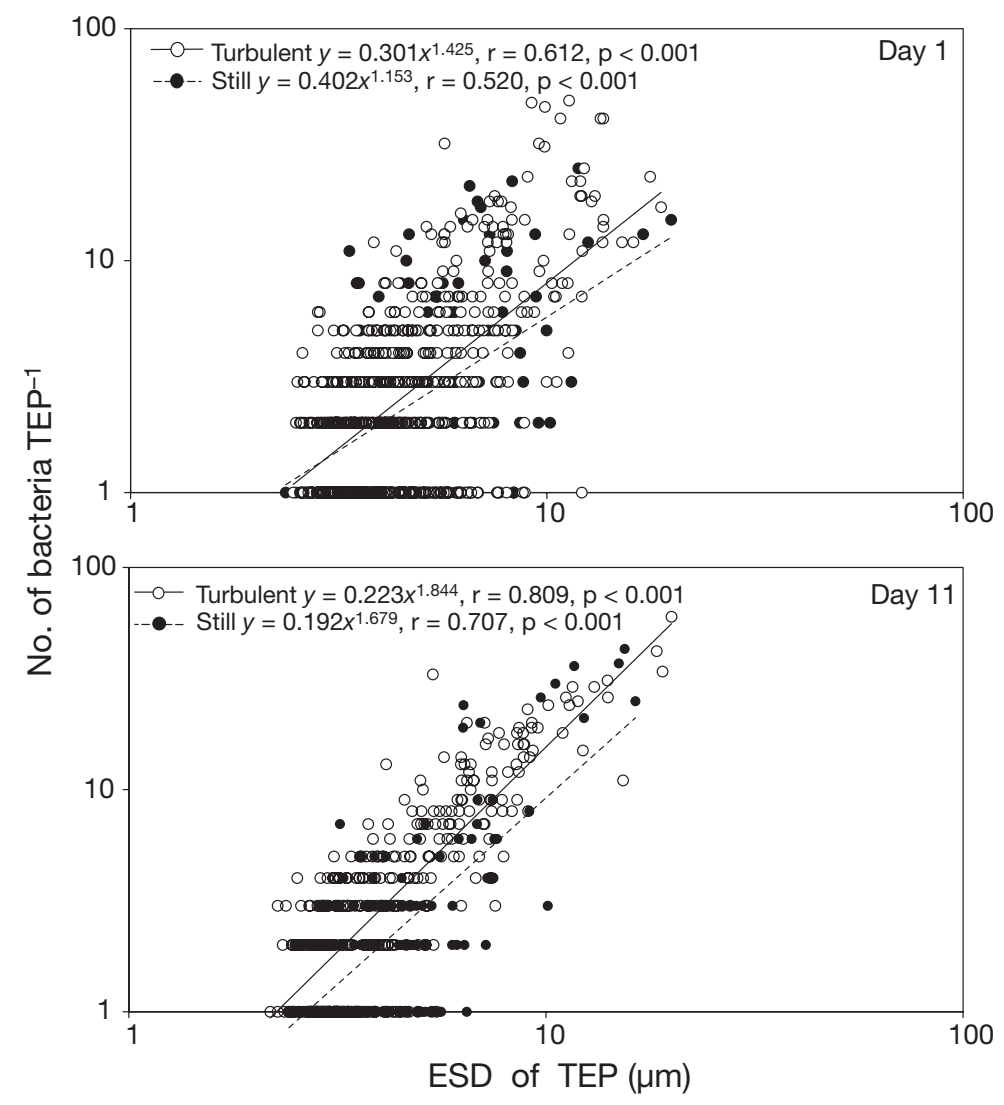

Fig. 2. Number of bacteria attached to a TEP as a function of its diameter $(d, \mu \mathrm{m})$ at Day 1 and Day 11 in still $(\mathrm{NT} 0, \mathrm{~T} 0, \bullet)$ and turbulent mesocosms (T2, T4, NT2, NT4, O). Regression lines were fitted to the observations. ESD: equivalent spherical diameter

The total numbers of attached bacteria in still and turbulent treatments were compared with the predicted abundances of attached bacteria estimated using encounter rate $B$ (from Kiørboe et al. 2002), TEP and total bacterial concentrations. Results showed that the total number of bacteria attached to TEP $\left(\mathrm{ml}^{-1}\right)$ in still tanks represented $\sim 33 \%$ (slope of bacterial concentration observed vs. predicted) of the calculated bacterial colonization, while attachment explained $40 \%$ of the predicted abundances of attached bacteria in turbulent tanks (Fig. 3).

\section{Bacterial abundance, production and percentage of attached bacteria}

At the start of the experiment, bacterial abundance in mesocosms ranged from $2 \times 10^{6}$ to $2.7 \times 10^{6}$ cells $\mathrm{ml}^{-1}$. Then a moderate increase in abundances was observed in enriched turbulent tanks, reaching a maximum of $4.7 \times 10^{6}$ cells ml $^{-1}$ on Day 3 at the higher tur- bulence level (NT4, Fig. 4A). A comparison of total bacterial concentrations between treatments showed no significant effect of nutrient addition or turbulence (ANOVA $F=0.11, \mathrm{p}=0.89, \mathrm{~N}=36$ ), although higher bacterial concentrations were observed in enriched turbulent tank NT2. However, the fraction of attached bacteria was higher in enriched turbulent tanks (Fig. 4B). TEP-attached bacteria ranged from 1.3 to $56.4 \%$ of the total numbers of bacteria. Low values occurred in non-enriched tanks, with an increase in proportions on Day 11 in turbulent tanks (12 and 15\% in T2 and T4, respectively). In nutrient-enriched tanks, the proportion of attached bacteria increased from Day 3 to reach peak concentrations in turbulent tanks NT2 and NT4 (36.4 and 56.4\%, respectively).

Table 2. Two-way ANCOVA of bacterial colonization of TEP at different sampling dates (except Day 9), with nutrients and turbulence as factors. N: number of samples, ns: non significant $(\mathrm{p}>0.05)$

\begin{tabular}{|lcccc|}
\hline Effect & $\begin{array}{c}\text { Nutrient }(A) \\
\mathrm{p}\end{array}$ & $\begin{array}{c}\text { Turbulence }(B) \\
\mathrm{p}\end{array}$ & $\begin{array}{c}A \times B \\
\mathrm{p}\end{array}$ & $\mathrm{N}$ \\
\hline Day 1 & $\mathrm{ns}$ & $\mathrm{ns}$ & $\mathrm{ns}$ & 859 \\
Day 3 & $\mathrm{ns}$ & 0.001 & $\mathrm{~ns}$ & 806 \\
Day 5 & $\mathrm{ns}$ & $4.5 \times 10^{-13}$ & $\mathrm{~ns}$ & 499 \\
Day 7 & $\mathrm{ns}$ & $\mathrm{ns}$ & $\mathrm{ns}$ & 395 \\
Day 11 & $\mathrm{ns}$ & 0.005 & 0.02 & 527 \\
& & & & \\
\hline
\end{tabular}

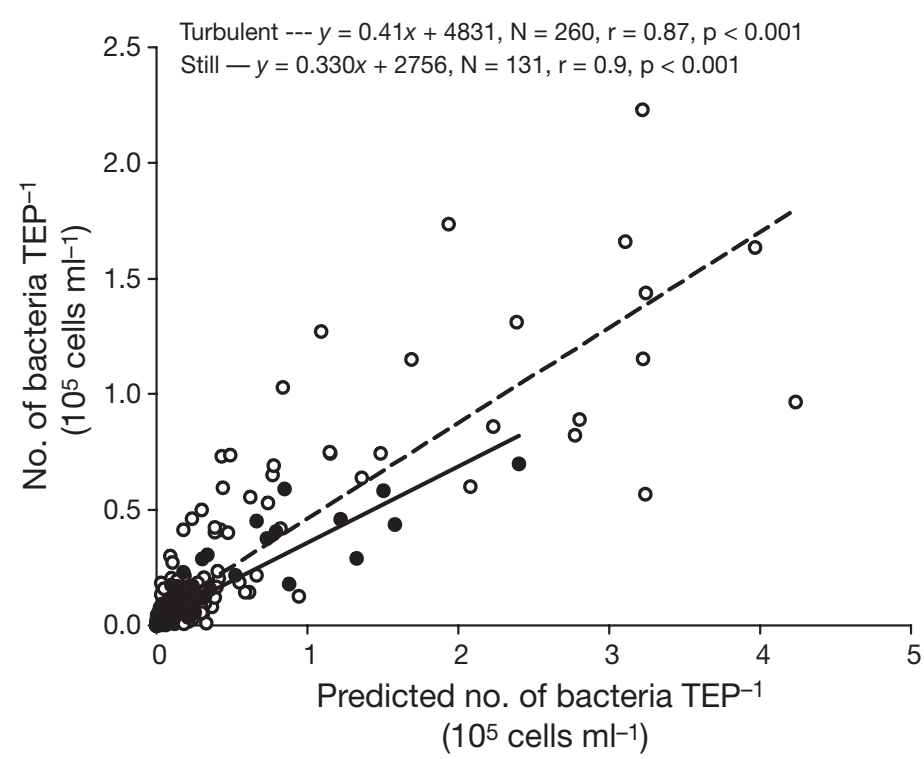

Fig. 3. Comparison between bacteria attached to TEP (cells $\mathrm{ml}^{-1}$ ) and predicted number of bacteria attached to TEP (based on encounter rate $B$, abundance and size of TEP and bacterial concentrations). Calculations were done for total numbers of bacteria attached to each size class of TEP for each treatment and sampling day in still $(\bullet)$ and turbulent $(O)$ mesocosms $(\mathrm{N}=383)$ 


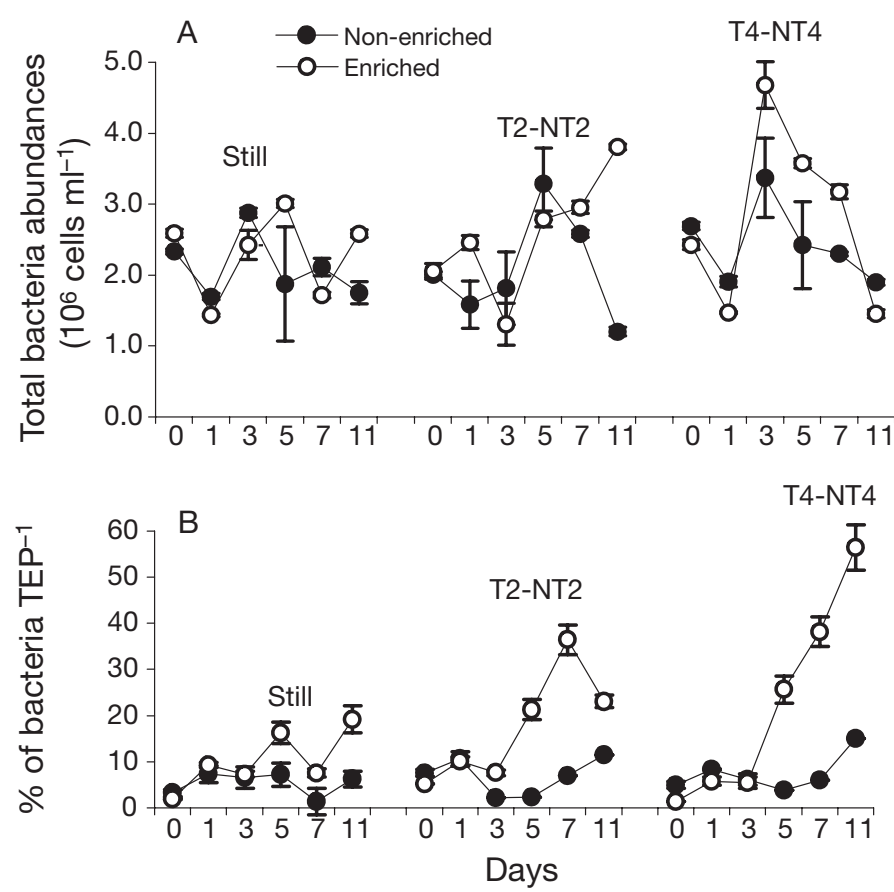

Fig. 4. (A) Total bacterial abundances $\left(10^{6}\right.$ cells $\left.\mathrm{ml}^{-1}\right)$ and (B) percentage of bacteria attached to TEP in still (T0, NT0) and turbulent (T2, T4, NT2, NT4) mesocosms. Error bars: SDs from replicate samples

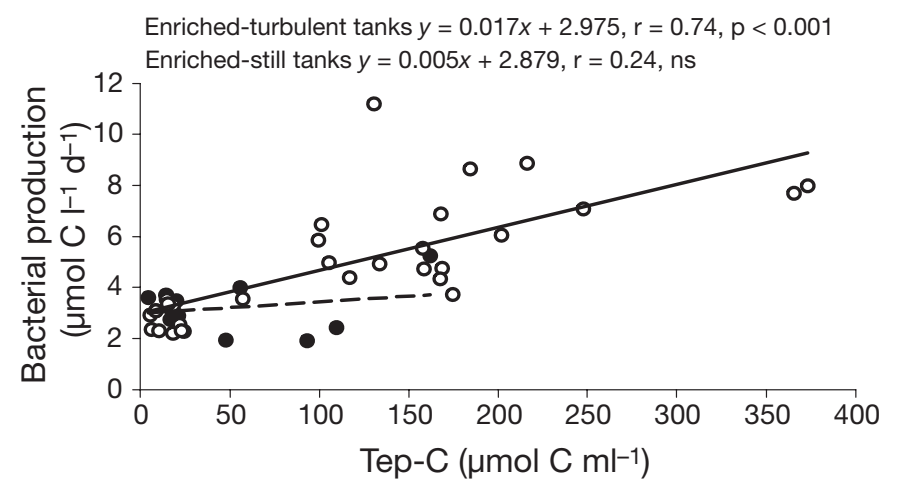

Fig. 5. Correlations between bacterial production ( $\mu \mathrm{mol} \mathrm{C \textrm {Cl } ^ { - 1 }}$ $\mathrm{d}^{-1}$ ) and carbon content of TEP (TEP-C, $\mu \mathrm{g} \mathrm{C} \mathrm{ml}^{-1}$ ) in enriched turbulent $(\mathrm{O}, \mathrm{NT} 2, \mathrm{NT} 4 ; \mathrm{n}=32 ; \mathrm{p}<0.001)$ and enriched still $(\bullet, N T 0 ; n=16 ; n s)$ mesocosms. Regression lines were fitted to the data

The bacterial production (BP) at the beginning of the experiment was on average $3.17 \pm 0.47 \mu \mathrm{mol} \mathrm{C} \mathrm{l}^{-1} \mathrm{~d}^{-1}$. In non-enriched tanks, BP remained low and decreased on Day 11 to $0.42,0.60$ and $0.93 \mu \mathrm{mol} \mathrm{C} \mathrm{l}^{-1} \mathrm{~d}^{-1}$ in $\mathrm{T} 0, \mathrm{~T} 2$ and $\mathrm{T} 4$, respectively. In nutrient-enriched mesocosms, higher production rates were observed with turbulence, with maximum BP $\left(11.21 \mu \mathrm{mol} \mathrm{C} \mathrm{l}^{-1}\right.$ $\mathrm{d}^{-1}$ ) on Day 9 in the NT2 tank. In all mesocosms, total bacterial abundance was neither correlated to TEP concentration nor to TEP-C content (Pearson's $r=0.253$ and 0.210 , respectively; $p>0.05$ ). Conversely, the normalized concentrations of attached bacteria were tightly coupled to TEP concentration and TEP-C content (Pearson's $\mathrm{r}=0.88$ and 0.89, respectively; $\mathrm{p}<$ 0.0001 ). The bacterial production rates in enriched turbulent mesocosms were positively correlated to TEP concentration (Pearson's $\mathrm{r}=0.67, \mathrm{p}<0.001$ ) and to TEP-C $;$ however, no correlation was found in enriched still tanks (Fig. 5). In non-enriched tanks, there were no significant correlations of bacterial production with TEP concentration and TEP-C content (Pearson's $\mathrm{r}=$ 0.04 and 0.07 , respectively).

\section{Community composition of bacteria and TEP}

Between the 2 domain probes used in this experiment, the EUB338 probe showed a high percentage of positive cells, with the proportion of Eubacteria detected varying from 55.7 to $88.7 \%$ of DAPI counts (median: 72.5 ; CV: 1.6 to 24.7 ). The high percentage

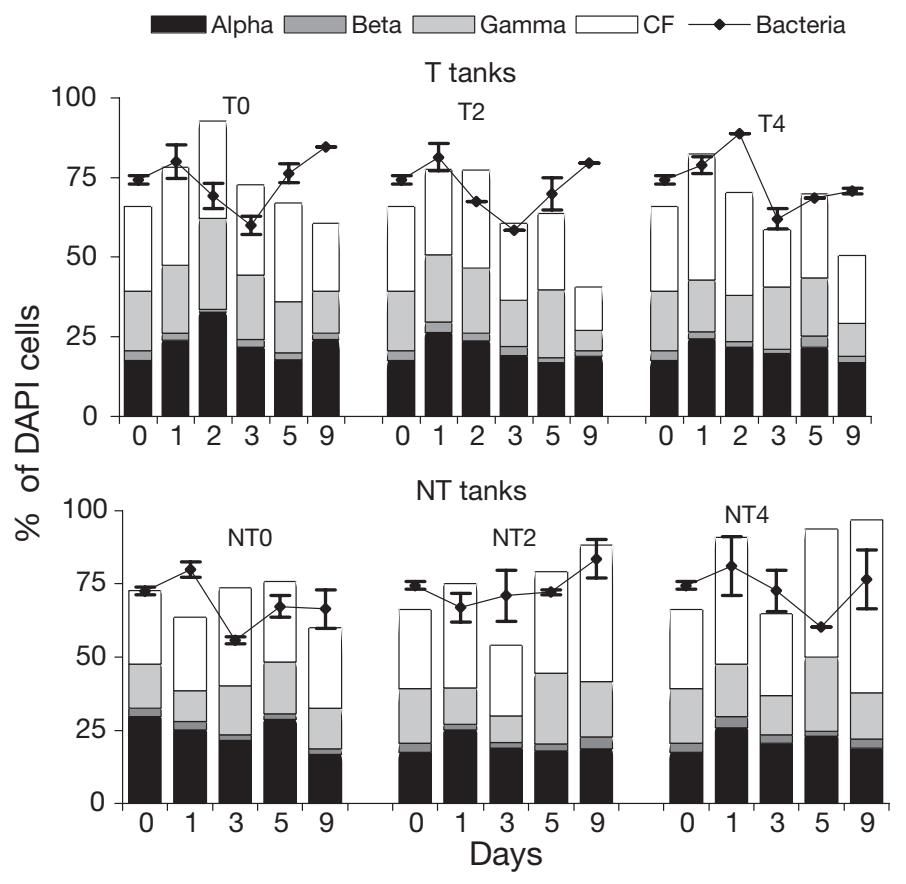

Fig. 6. Community structure of the bacterioplankton as determined by in situ hybridization with rRNA-targeted fluorescent oligonucleotide probes in different mesocosms. Probe data are given as \% of DAPI cells. Specifications of the probes are as follows: EUB338 for Bacteria, ALF968, BET42a and GAM42a for Alpha, Beta and Gamma-subclass Proteobacteria, respectively, and CF319 for the Cytophaga-flavobacterium cluster. Data from Day 2 are missing in nutrientenriched tanks 
of positive cells indicated high activity and growth of bacteria. In general, the proportion of Eubacteria decreased at Days 3 to 5 and increased again until the end of the experiment (Fig. 6). There were no significant differences in the relative abundance of Eubacteria between treatments $\left(\mathrm{ANOVA}_{i} F=0.57, \mathrm{p}=0.54\right.$, $\mathrm{N}=66$ ). The proportion of cells detected with the Archaea probe was below the detection limit. The fraction of microorganisms hybridizing with the Alphaproteobacteria probe increased from 16 to $33.5 \%$ of DAPI counts (median: 20.4), while those hybridizing with the Betaproteobacteria and Gammaproteobacteria probes varied from 1.3 to $5 \%$ (median: 3.1 ) and 6 to $28.7 \%$ (median: 17.8), respectively. Members of the Cytophaga-Flavobacterium cluster are the most abundant and accounted for 13.7 to $59 \%$ of total cells in the mesocosms (median: 27.3; CV: 1.6 to 24.7). Due to the rather good detection efficiency of Eubacteria, the sum of the fractions of the Alpha, Beta, Gamma-subclass and Cytophaga-Flavobacterium cluster detected by the various probes used ranged from 33 to $75 \%$ of the cells detected by EUB338. Results showed few effects of turbulence and nutrient availability on the proportion of different proteobacteria subclasses with time. The most important changes occurred in the Cytophaga-Flavobacterium cluster. In still tanks, the proportion of cells detected with the CF319 probe was nearly constant throughout the experiment. However, in turbulent tanks, the dynamics were complex. While the proportion of cells detected decreased from Day 3 to the end of the experiment in non-enriched tanks, it increased to reach 46 and $59 \%$ of total cells at Day 9 in mesocosms receiving inorganic nutrients and turbulence together (NT2 and NT4 tanks, respectively; Fig. 7). The increase in the proportion of the CytophagaFlavobacterium cluster corresponded with the diatom bloom and subsequent TEP formation (Fig. 1A,B). The analysis of the composition of particle-associated bac-

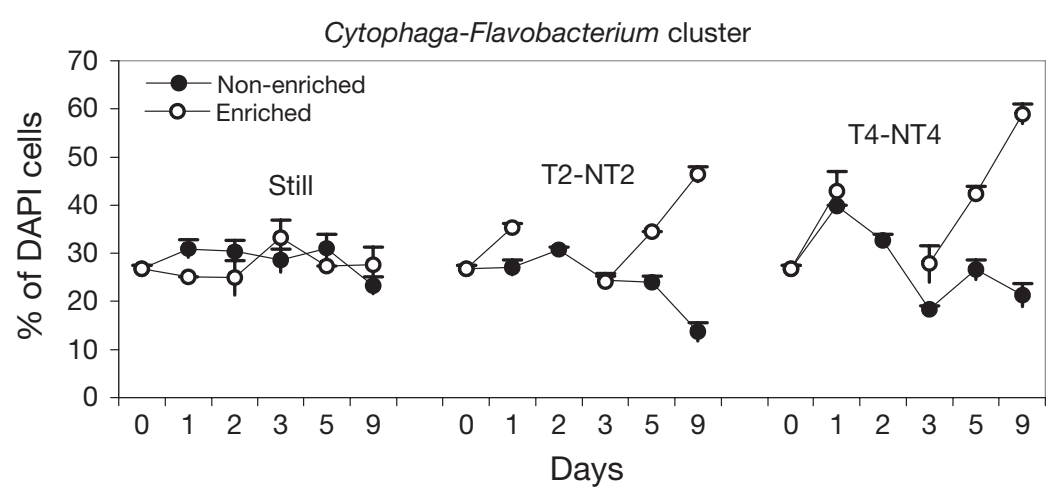

Fig. 7. Percentages of Cytophaga-flavobacterium clusters in the different mesocosms. Data are given as \% of DAPI cells teria (using filters stained with Alcian blue and FISH) showed that the Cytophaga-Flavobacterium population increased with bloom senescence on Day 9, with this population comprising 85 and $90 \%$ of the total attached bacteria at intermediate and high levels of turbulence, respectively. In mesocosms without turbulence, attached bacteria were characterized by a mixture of populations mainly composed of the Cytophaga-Flavobacterium cluster and Alphaproteobacteria (33 and 28\% of the total DAPI-stained cells, respectively,).

\section{DISCUSSION}

\section{TEP-heterotrophic bacteria interactions}

Bacteria colonized most of the TEP present in the mesocosms, with significant differences in colonization between treatments. TEP may act as efficient scavengers for many substances such as amino acids (Schuster et al. 1998). TEP is also a direct site for sorption of nutrients and trace metals, such as manganese and iron (Beauvais 2003), thereby providing a substrate for bacterial growth (Kirchman et al. 2003). The effects of nutrient addition and turbulence on TEP dynamics as studied by Beauvais et al. (2006) in the same mesocosms showed that TEP production is more a function of higher phytoplankton concentrations achieved in nutrient-enriched treatments.

The effect of turbulence was likely indirect, i.e. through an increase in the growth rates of diatoms that actively exude TEP precursors, particularly when nutrients become exhausted. Variations in microbial colonization of TEP have been explained by variability in the composition of TEP precursors, in degradability of TEP (Kepkay \& Johnson 1988, Passow \& Alldredge 1994) and in grazing pressure (Mari et al. 2004). In the present experiment, the increase in the rate of bacterial colonization of TEP appeared linked to the rapid formation of TEP after the diatom bloom in enriched turbulent tanks. Freshly produced TEP are probably more reactive and readily colonizing them could be more beneficial for bacteria. Colonization patterns in the present study suggest that interactions between TEP and bacteria may be more complex. The addition of nutrients and turbulence in mesocosms did not significantly support higher bacterial abundance and no correlation was found between bacterial concentrations and TEP. However, the higher colonization rates 
in nutrient-enriched turbulent mesocosms (up to $56.4 \%$ ) was accompanied by higher bacterial production rates and was positively correlated to TEP. These correlations highlight the finding that the higher bacterial productivity was due to a larger fraction of attached bacteria.

It has been shown in freshwater environments that particle-associated bacteria can account for a large proportion of the total bacterial production (Simon et al. 2002). While total bacterial numbers remained more or less constant in our experiment and did not reflect any changes in bacterial activities, changes in bacterial production occurred with simultaneous changes in the community structure (i.e. the percentages of the Cytophaga-Flavobacterium cluster increased significantly, this group being the dominant bacteria attached to TEP). Among the marine heterotrophic bacterioplankton, members of the CytophagaFlavobacteria-Bacteroides (CFB) phylum are known to be common as attached bacteria (DeLong et al. 1993, Riemann et al. 2000). Cytophaga-Flavobacteria also represented a significant part of surface-attached and free-living microbial assemblages in nutrient-rich micro-environments associated with phytoplankton blooms (Fandino et al. 2005). The dominance of surface-attached bacteria on marine snow or detritus could be explained by the presence of specific profiles of hydrolytic enzymes adapted to degrade biopolymers including complex polysaccharides, indicating their major role in the marine carbon cycle (Bauer et al. 2006). Lemarchand et al. (2006) have shown that the Cytophaga-Flavobacterium group and Betaproteobacteria have higher enzymatic activities than free-living bacteria and are the dominant groups attached to particles in lakes. They also found positive relationships between TEP and glycolytic activities.

Comparison of Proteobacteria in our mesocosms revealed minor variation in the relative abundance of the different subclasses with time and with treatments. Moreover, we detected a decrease in the proportion of the Cytophaga-Flavobacterium population in non-enriched turbulent tanks. The decrease could have been due to less carbon excreted by phytoplankton in the relatively nutrient-poor mesocosms, which perhaps favored the appearance of other phylogenetic groups adapted for growth in low substrate concentrations, most notably Planctomycetales that is widespread in marine ecosystems and may have been missed by our EUB338 probe (Gade et al. 2004). However, we cannot exclude confinement effects or other factors such as viral and/or grazing controls, which were not considered in the present study, but may also influence the abundance and diversity of the bacterial communities (Simek et al. 1997).

\section{Turbulence effect on attached bacteria}

In the present experiments, the abundance of attached bacteria increased significantly with TEP size in all treatments. Other authors have also reported this relationship for exopolymeric particles as well as for other marine aggregates (Mari \& Kiørboe 1996, Ploug et al. 1999, Simon et al. 2002). The exponent $(\sim 1.5)$ of this relationship found by Mari \& Kiørboe (1996) has been attributed to the fact that TEP have a fractal dimension. Consequently, the number of attached bacteria is directly proportional to TEP porosity. The present results showed that the slope values for the number of bacteria scaled with TEP size had large differences, varying from 1.15 on Day 1 in still tanks to 2.04 on Day 11 in turbulent tanks. Comparison between these slopes indicated that, for a given TEP diameter, bacterial colonization was greater in mesocosms under turbulence. This can be explained by the fact that bacteria are not inert particles and colonization is not only influenced by TEP size and concentration, but also by specific bacterial responses to their chemical and physical environment (Grossart \& Ploug 2001, Grossart et al. 2007). According to Karp-Boss et al. (1996), free bacteria with cells smaller than the Kolmogorov and Batchelor length scale should not benefit from a flux of nutrients owing to turbulent advection as their inorganic nutrient uptake is dominated primarily by molecular diffusion. However, turbulence may enhance the flux of high molecular weight substrates such as serum albumin (BSA) and the polysaccharide dextran towards cells (Confer \& Logan 1991). These indicate that at higher shear rates, fluid motion will decrease the diffusive sublayer thickness of bacteria, thereby increasing the nutrient uptake rate. Peters et al. (1998) observed higher bacterial abundance and activity under turbulence in a microbial community. These changes were accompanied by a higher nutrient recycling and an increase in dissolved organic matter flux to bacteria. In contrast, Moeseneder \& Herndl (1995) observed lower bacterial production under turbulent conditions in the laboratory when phytoplankton and particles were present, although the turbulence rates used were higher than naturally occurring levels. Attached bacteria in our experiment could benefit from the effective increase in nutrient flux to the particle owing to turbulent advection by increasing their growth rates when nutrients are not saturated.

Kiørboe \& Jackson (2001) suggested that bacteria could actively colonize aggregates. Comparing total bacteria attached to TEP in our experiment with predicted attachment rates within $1 \mathrm{~h}$ showed that $\sim 37 \%$ of bacteria encountering a TEP colonized these particles, with colonization rates being higher (44\%) in tur- 
bulent tanks. The present results are crude estimations, but are consistent with those derived by Kiørboe et al. (2002), who on average estimated that 50 and $92 \%$ of the bacteria will encounter an aggregate within $7 \mathrm{~h}$ and in $1 \mathrm{~d}$, respectively. As the experiment was conducted on a time scale of days, we observed some time-dependent differences, from little colonization at the beginning of the study to increased colonization at the end. Not all bacteria encountering a particle will necessarily attach; the encounter rate depends on the size distribution and concentration of particles and on the concentration and motility of bacteria (Kiørboe et al. 2002). However, even with the variability in encounter rates, the higher coefficients in turbulent tanks suggest that the shear present under turbulence would enhance the encounter probability. Even if stickiness was not measured in this experiment, we assumed a high stickiness coefficient of TEP (Passow et al. 1994, Logan et al. 1995) after a diatom bloom, which might enhance coagulation efficiency that could facilitate bacterial attachment. Thus, turbulence may affect bacteria-TEP interactions indirectly through its effects on the availability of different substrates, as well as directly by increasing encounter rates. Consequently, attachment to particles such as TEP can result in significant advantages for bacteria. Fluid advection through porous aggregates is higher than through dispersed particles (Logan \& Hunt 1987).

The present results show that the rapid TEP formation triggered by the release of large quantities of dissolved organic carbon after the phytoplankton bloom likely stimulated the activity and growth of attached bacteria. It appears that the added nutrients and subsequent TEP production can be used by bacteria more efficiently under turbulent conditions through a shift in group-specific composition towards more attached bacteria with higher production rates.

This study also shows the highly dynamic nature of TEP and emphasizes its role as organic substrates for bacteria. TEP could greatly influence the composition and activity of particle-associated bacteria. Turbulence may produce synergistic effects changing the availability of different organic matter fractions to bacteria and favoring attachment rates.

Acknowledgements. The authors thank all the participants of NTAP workshop at Speland Marine Station for helpful discussions and C. Marrasé and anonymous reviewers for helpful comments. We also thank J. Dolan for improving the English. Access to installations was funded by the Large-Scale Facility of the University of Bergen. This research was part of the shared cost research project NTAP EVK3-CT-2000-00022.

\section{LITERATURE CITED}

Alldredge AL, Passow U, Logan BE (1993) The abundance and significance of a class of large, transparent organic particles in the ocean. Deep-Sea Res 40:1131-1140

Amann RI, Krumholz L, Stahl DA (1990) Fluorescent-oligonucleotide probing of whole cells for determinative, phylogenetic, and environmental studies in microbiology. J Bacteriol 172:762-770

Azam F, Fenchel T, Field JG, Gray JS, Meyer-Reil LA, Thingstad $F$ (1983) The ecological role of water-column microbes in the sea. Mar Ecol Prog Ser 10: 257-263

Bauer M, Kube M, Teeling H, Richter M and others (2006) Whole genome analysis of the marine Bacteroidetes 'Gramella forsetii' reveals adaptations to degradation of polymeric organic matter. Environ Microbiol 8:2201-2213

Beauvais S (2003) Study of transparent exopolymeric particles (TEP) in the marine environment: dynamics and role within the carbon cycle. PhD dissertation, University of Paris VI, p 217

Beauvais S, Pedrotti ML, Egge J, Iversen K, Marrasé C (2006) Effects of turbulence on TEP dynamics under contrasting nutrient conditions: implications for aggregation and sedimentation processes. Mar Ecol Prog Ser 323:47-57

- Bergstedt MS, Hondzo MM, Cotner JB (2004) Effects of small scale fluid motion on bacterial growth and respiration. Freshw Biol 49:28-40

Bowen JD, Stolzenbach KD, Chisholm SW (1993) Simulating bacterial clustering around phytoplankton cells in a turbulent ocean. Limnol Oceanogr 38:36-51

Confer DR, Logan BE (1991) Increased bacterial uptake of macromolecular substrates with fluid shear. Appl Environ Microbiol 57:3093-3100

DeLong EF, Franks DG, Alldredge AL (1993) Phylogenetic diversity of aggregate-attached vs. free-living marine bacterial assemblages. Limnol Oceanogr 38:924-934

Dolan JR, Sall N, Metcalfe A, Gasser B (2003) Effects of turbulence on the feeding and growth of a marine oligotrich ciliate. Aquat Microb Ecol 31:183-192

> Engel A, Thomas S, Riebesell U, Rochelle-Newall E, Zondervan I (2004) Polysaccharide aggregation as a potential sink of marine dissolved organic carbon. Nature 428:929-932

Fandino LB, Riemann L, Steward GF, Azam F (2005) Population dynamics of Cytophaga-Flavobacteria during marine phytoplankton blooms analyzed by real-time quantitative PCR Aquat Microb Ecol 40:251-257

Gade D, Schlesner H, Glockner FO, Amann R, Pfeiffer S, Thomm M (2004) Identification of Planctomycetes with order-, genus-, and strain-specific 16S rRNA-targeted probes. Microb Ecol 47:243-251

Grossart HP, Ploug H (2001) Microbial degradation of organic carbon and nitrogen on diatom aggregates. Limnol Oceanogr 46:267-277

Grossart HP, Tang KW, Kiørboe T, Ploug H (2007) Comparison of cell-specific activity between free-living and attached bacteria using isolates and natural assemblages. FEMS Microbiol Lett 266:194-200

> Hill PS, Nowell ARM, Jumars PA (1992) Encounter rate by turbulent shear of particles similar in diameter to the Kolmogorov scale. J Mar Res 50:643-668

Karp-Boss L, Boss E, Jumars J (1996) Nutrient fluxes to planktonic osmotrophs in the presence of fluid motion. Oceanogr Mar Biol Annu Rev 37:71-107

> Kepkay PE, Jonhson BD (1988) Microbial response to organic particle generation by surface coagulation in seawater. Mar Ecol Prog Ser 48:193-198

Kiørboe T (1997) Small-scale turbulence, marine snow formation, and planktivorous feeding. Sci Mar 61:141-158

Kiørboe T, Jackson GA (2001) Marine snow, organic solute plumes, and optimal sensory behaviour of bacteria. Limnol 
Oceanogr 46:1309-1318

Kiørboe T, Grossart HP, Ploug H, Tang K (2002) Mechanisms and rates of bacterial colonization of sinking aggregates. Appl Environ Microbiol 68:3996-4006

Kirchman DL, K'nees E, Hodson RE (1985) Leucine incorporation and its potential as a measure of protein synthesis by bacteria in natural aquatic systems. Appl Environ Microbiol 49:599-607

Kirchman DL, Hoffman KA, Weaver R, Hutchins DA (2003) Regulation of growth and energetics of a marine bacterium by nitrogen source and iron availability. Mar Ecol Prog Ser 250:291-296

Knoll S, Zwisler W, Simon M (2001) Bacterial colonization of early stages of limnetic diatom microaggregates. Aquat Microb Ecol 25:141-150

Koike I, Shigemitsu H, Kazuki T, Kazuhiro K (1990) Role of submicrometer particles in the ocean. Nature 345:242-244

- Lazier JRN, Mann KH (1989) Turbulence and the diffusive layers around small organisms. Deep-Sea Res 36:1721-1733

Lemarchand C, Jardillier L, Carrias JF, Richardot M, Debroas D, Sime-Ngando T, Amblard C (2006) Community composition and activity of prokaryotes associated to detrital particles in two contrasting lake ecosystems. FEMS Microbiol Ecol 57:442-451

Logan BE, Hunt JR (1987) Advantages to microbes of growth in permeable aggregates in marine systems. Limnol Oceanogr 35:1034-1048

Logan BE, Grossart HP, Simon M (1994) Direct observation of phytoplankton, TEP and aggregates on polycarbonate filters using brightfield microscopy. J Plankton Res 16:1811-1815

Logan BE, Passow U, Alldredge AL, Grossar HP, Simon M (1995) Rapid formation and sedimentation of large aggregates is predictable from coagulation rates (half-lives) of transparent exopolymer particles (TEP). Deep-Sea Res 42:203-214

MacKenzie BR, Legget WC (1993) Wind-based models for estimating the dissipation rates of turbulent energy in aquatic environments: empirical comparisons. Mar Ecol Prog Ser 94:207-216

Malits A, Peters F, Bayer-Giraldi M, Marrasé C, Zoppini A, Guadayol O, Alcaraz M (2004) Effects of small-scale turbulence on bacteria: a matter of size. Microb Ecol 48:287-299

Mann KH, Lazier JRN (1996) Dynamics of marine ecosystems. Biological-physical interactions in the oceans. Blackwell Scientific, Boston, MA

Mari X (1999) Carbon content and C:N ratio of transparent exopolymeric particles (TEP) produced by bubbling exudates of diatoms. Mar Ecol Prog Ser 183:59-71

Mari X, Kiørboe T (1996) Abundance, size distribution and bacterial colonization of transparent exoplymeric particles (TEP) during spring in the Kattegat. J Plankton Res 18:969-986

Mari X, Beauvais S, Lemée R, Pedrotti ML (2001) Non-Redfield C:N ratio of transparent exopolymeric particles in the northwestern Mediterranean Sea. Limnol Oceanogr 46:1831-1836

Mari X, Rassoulzadegan F, Brussaard CPD (2004) Role of TEP in the microbial food web structure. II. Influence on the ciliate community structure. Mar Ecol Prog Ser 279:23-32

Moeseneder MM, Herndl, GJ (1995) Influence of turbulence on bacterial production in the sea. Limnol Oceanogr 40:1466-1473

$>$ Ouverney CC, Fuhrman JA (2000) Marine planktonic Archaea take up amino acids. Appl Environ Microbiol
66:4829-4833

Parsons TR, Maita Y, Lalli CM (1984) A manual of chemical and biological methods for sea water analysis. Pergamon Press, Oxford

Passow U, Alldredge AL (1994) Distribution, size and bacterial colonization of transparent exopolymer particles (TEP) in the ocean. Mar Ecol Prog Ser 113:185-198

Passow U, Alldredge AL, Logan BE (1994) The role of particulate carbohydrate exudates in the flocculation of diatom blooms. Deep-Sea Res 41:335-357

Pernthaler J, Glöckner FO, Schönhuber W, Amann R (2001) Fluorescence in situ hybridization (FISH) with rRNA-target oligonucleotide probes. In: Paul JH (ed) Marine microbiology. Method Microbiol 30:207-226

Peters F, Marrasé C, Gasol JM, Montserrat Sala M, Arin L (1998) Effects of turbulence on bacterial growth mediated through food web interactions. Mar Ecol Prog Ser 172:293-303

Peters F, Marrasé C, Havskum H, Rassoulzadegan F, Dolan J, Alcaraz M, Gasol JM (2002) Turbulence and the microbial food web: effects on bacterial losses to predation and on community structure. J Plankton Res 24:321-331

> Pinhassi J, Sala MM, Havskum H, Peters F, Guadayol Ò, Malits A, Marrasé C (2004) Changes in bacterioplankton composition under different phytoplankton regimens. Appl Environ Microbiol 70:6753-6766

Ploug H, Grossart HP, Azam F, Jørgensen BB (1999) Photosynthesis, respiration, and carbon turnover in sinking marine snow from surface waters of Southern California Bight: implications for the carbon cycle in the ocean. Mar Ecol Prog Ser 179:1-11

Porter KG, Feig YS (1980) The use of DAPI for identifying and counting aquatic microflora. Limnol Oceanogr 25:943-948

Radic T, Ivancic I, Fuks D, Radic J (2006) Marine bacterioplankton production of polysaccharidic and proteinaceous particles under different nutrient regimes. FEMS Microbiol Ecol 58:333-342

Riemann L, Steward GF, Azam F (2000) Dynamics of bacterial community composition and activity during a mesocosm diatom bloom. Appl Environ Microbiol 66:578-587

> Schuster S, Herndl GJ (1995) Formation and significance of transparent exopoylmeric particles in the northern Adriatic Sea. Mar Ecol Prog Ser 124:227-236

Schuster S, Arrieta JM, Herndl GJ (1998) Adsorption of dissolved free amino acids on colloidal DOM enhances colloidal DOM utilization but reduces amino acid uptake by orders of magnitude in marine bacterioplankton. Mar Ecol Prog Ser 166:99-108

Seymour JR, Mitchell JG, Pearson L, Waters RL (2000) Heterogeneity in bacterioplankton abundance from 45 millimetre resolution. Aquat Microb Ecol 22:143-153

Simek K, Vrba J, Pernthaler J, Posch T, Hartman P, Nedoma J, Psenner R (1997) Morphological and compositional shifts in an experimental bacterial community influenced by protists with contrasting feeding modes. Appl Environ Microbiol 63:587-595

Simon M, Azam F (1989) Protein content and protein synthesis rates of planktonic marine bacteria. Mar Ecol Prog Ser 51:201-213

Simon M, Grossart HP, Schweitzer B, Ploug H (2002) Microbial ecology of organic aggregates in aquatic ecosystems. Aquat Microb Ecol 28:175-211

Smith DC, Simon M, Alldredge AL, Azam F (1992) Intense hydrolytic enzyme activity on marine aggregates and implications for rapid particle dissolution. Nature 359:139-141

Smith DC, Steward GF, Long RA, Azam F (1995) Bacterial mediation of carbon fluxes during a diatom bloom in a 
mesocosm. Deep-Sea Res 42:75-97

Stiansen JE, Sundby S (2001) Improved methods for generating and estimating turbulence in tanks suitable for fish larvae experiments. Sci Mar 65:151-167

Stoderegger KE, Herndl GJ (1998) Production and release of bacterial capsular material and its subsequent utilization by marine bacterioplankton. Limnol Oceanogr 43:877-884

Stoderegger KE, Herndl GJ (1999) Production of exopolymer

Editorial responsibility: Craig Carlson,

Santa Barbara, California, USA particles by marine bacterioplankton under contrasting turbulence conditions. Mar Ecol Prog Ser 189:9-16

Verdugo P, Alldredge AL, Azam F, Kirchmand DL, Passow U, Santschi PH (2004) The oceanic gel phase: a bridge in the DOM-POM continuum. Mar Chem 92:67-85

Wells ML, Goldberg ED (1994). The distribution of colloids in the North Atlantic and Southern Ocean. Limnol. Oceanogr. 39:286-302

Submitted: December 20, 2007; Accepted: April 9, 2009 Proofs received from author(s): June 15, 2009 